\title{
Physicochemical and sensory characterization of three different portions from commercial pirarucu (Arapaima gigas) fillets
}

\author{
Caracterização físico-química e sensorial de três diferentes porções de filés \\ comerciais de pirarucu (Arapaima gigas)
}

\section{Júlia de Souza Lira Santos', Eliane Teixeira Mársico', Miguel Antônio Cinquini², Flávio Alves da Silva², Carlos Adam Conte Junior', Maria Lúcia Guerra Monteiro1* ${ }^{10}$}

${ }^{1}$ Universidade Federal Fluminense (UFF), Departamento de Tecnologia de Alimentos, Niterói/RJ - Brasil

2 Universidade Federal de Goiás (UFG), Departamento de Engenharia de Alimentos, Goiânia/GO - Brasil

\section{${ }^{*}$ Corresponding Author}

Maria Lúcia Guerra Monteiro, Universidade Federal Fluminense (UFF), Departamento de Tecnologia de Alimentos, Rua Vital Brazil Filho, 64, Santa Rosa, CEP: 24230-340, Niterói/RJ - Brasil, e-mail: mariaguerra@id.uff.br

Cite as: Physicochemical and sensory characterization of three different portions from commercial pirarucu (Arapaima gigas) fillets. Braz. J. Food Technol., v. 21, e2017178, 2018.

Received: Nov. 16, 2017; Accepted: Mar. 08, 2018

\section{Abstract}

The objective of the present study was to investigate the relevant physicochemical and sensory parameters of three different Arapaima gigas muscle portions. Cranial, medial and caudal portions were analysed regarding their proximate compositions, instrumental colour and texture parameters, and sensory evaluations. The medial and caudal portions exhibited the greatest $(P<0.05)$ lipid contents and energy values and the lowest $(P<0.05)$ moisture and carbohydrate levels. The protein contents were similar $(P>0.05)$ for the different muscle portions. Before cooking, the medial and caudal portions displayed the greatest $(P<0.05)$ values for lightness, redness, hardness and chewiness. After cooking, no differences $(P>0.05)$ were observed between the different muscle portions for the instrumental colour parameters, while the medial portion exhibited lower $(P<0.05)$ values for hardness and chewiness as compared to the caudal portion. The cranial portion received the lowest $(P<0.05)$ scores for flavour and overall liking. Thus the Arapaima gigas medial and caudal muscle portions presented the greatest potentials to satisfy the consumer requirements.

Keywords: Freshwater fish; Proximate composition; Instrumental analyses; Colour; Texture; Acceptability.

\section{Resumo}

O objetivo do presente estudo foi investigar relevantes parâmetros físico-químicos e sensoriais de três diferentes porções musculares da espécie Arapaima gigas. Porções cranial, medial e caudal foram analisadas em relação a composição centesimal, parâmetros instrumentais de cor e textura e atributos sensoriais. As porções medial e caudal apresentaram o maior conteúdo de lipídeos e valor energético $(P<0,05)$; no entanto, os menores teores de umidade e carboidrato $(P<0,05)$. O conteúdo de proteína foi similar $(P>0,05)$ entre as diferentes porções musculares. Antes do cozimento, as porções medial e caudal demonstraram os maiores valores de $L^{*}, a^{*}$, dureza e mastigabilidade $(P<0,05)$. Após o cozimento, não se observou diferença $(P>0,05)$ nos parâmetros instrumentais de cor entre as diferentes porções musculares. A porção medial apresentou menor dureza e mastigabilidade $(P<0,05)$, quando comparada à porção caudal. A porção cranial apresentou o menor escore de sabor e impressão global $(P<0,05)$. Portanto, as porções musculares medial e caudal de Arapaima gigas demonstraram potencial superior para satisfazer as exigências dos consumidores.

Palavras-chave: Peixe dulcícola; Composição centesimal; Análises instrumentais; Cor; Textura; Aceitabilidade.

\section{Introduction}

The global demand for fresh and chilled fish has increased in recent years (FAO, 2016). Amongst freshwater fish species, the pirarucu (Arapaima gigas) has received great attention

due to its high weight gain and carcass yield, representing an excellent potential for global aquaculture production. However, the high carcass yield generates a large fillet, diverging from 
current consumer patterns and impairing retail displays. Nevertheless, Arapaima gigas presents adequate sensorial qualities (FOGAÇA et al., 2011).

Amongst the determinant sensory parameters for food acceptance, colour and texture are the most important (COPPES et al., 2002; FAUSTMAN et al., 2010; MANCINI; HUNT, 2005), indicating freshness and wholesomeness, with a significant effect on product acceptability and consumer purchase decisions (RINCÓN et al., 2016).

Both the colour and texture properties can be evaluated more accurately by instrumental methods (BREWER et al., 2001; VÁCHA et al., 2013). The texture profile analysis (TPA) is determined by a force-time curve resulting from compression forces, simulating mouth biting and chewing, presenting adequate correlations with sensory evaluations (CARDOSO et al., 2009; XIONG et al., 2006). The instrumental colour analysis can be carried out by colorimetric or spectrophotometric techniques, which are based on the capture of light reflected from the sample surface by a detector, which is interpreted by a microprocessor, simulating the interaction between eye and brain with respect to colour perception (AMSA, 2012). Both instrumental colour and texture methods are simple and useful techniques to determine product quality, and are usually evaluated in association with sensory assays (CARDOSO et al., 2009; LIU et al., 2003).

The sensory attributes, instrumental colour and texture parameters of fish species are well documented in the literature (CHEN et al., 2015; KULAWIK et al., 2016; MOLINA et al., 2014; RINCÓN et al., 2016). However, no such studies are available for these parameters in pirarucu fillets. Therefore the aim of the present study was to investigate the relevant physicochemical and sensory parameters of three different pirarucu muscle portions (cranial, medial and caudal), in order to add value to these products as a strategic alternative to meet consumer demands for the commercialization of pirarucu.

\section{Material and methods}

\subsection{Experimental design and sample preparation}

A. gigas fillets $(2.72 \mathrm{~kg} \pm 0.46 \mathrm{~g}$ in weight and $70.7 \mathrm{~cm} \pm 7.07 \mathrm{~cm}$ in length) were obtained from a fishery located in Bonfinópolis, Goiás, Brazil (16³6'52.2" S 048 59'58.1" W). The fish were randomly selected from the same batch at a fish farm in São Luis de Montes Belos, Goiás, Brazil (16³1'37.6" S 050²4'28.5” W), slaughtered, and transported on ice $\left(0 \pm 1^{\circ} \mathrm{C}\right)$ to the fishery, where the heads, viscera and fillets were removed. The fillets were then frozen $\left(-20^{\circ} \mathrm{C}\right)$, packed in a polystyrene box containing ice $\left(0 \pm 1^{\circ} \mathrm{C}\right)$, and transported to the laboratory, where the samples were thawed overnight $\left(4 \pm 1^{\circ} \mathrm{C}\right)$, weighed, measured and divided into three equal portions based on the total length, as follows: cranial, medial and caudal. Each muscle portion measured $23.5 \pm 2.33 \mathrm{~cm}$ and weighed $970 \mathrm{~g} \pm 0.03 \mathrm{~g}, 990 \mathrm{~g} \pm 0.01 \mathrm{~g}$ and $760 \mathrm{~g} \pm 0.47 \mathrm{~g}$, respectively. The different muscle portions were analysed for their proximate compositions, instrumental colour parameters ( $L^{*}, a^{*}$ and $b^{*}$ values), instrumental texture attributes (hardness, chewiness, springiness and cohesiveness), acceptance test and purchase intention.

Prior to the analyses, each muscle portion was recut into cubic samples $(2 \times 2 \times 2 \mathrm{~cm})$, which were randomly selected to determine the proximate composition, $L^{*}, a^{*}$ and $b^{*}$ values, hardness, chewiness, springiness and cohesiveness. The remainder of each muscle portion was then steamed until the internal product temperature reached $72^{\circ} \mathrm{C}$, and maintained there for $1 \mathrm{~min}$, according to FDA specifications for fish and fishery products, based on the effective reduction of Listeria monocytogenes (FDA, 2011). In addition, temperatures above $70^{\circ} \mathrm{C}$ are considered safe for the human consumption of fish and fish products (LATIMER JUNIOR, 2012). After cooking, the different muscle portions were recut as aforementioned and randomly distributed for the sensory evaluation and the instrumental colour and texture analyses.

The whole experiment was repeated twice $(n=2)$ and the analyses were carried out in triplicate, except for the $L^{*}, a^{*}$ and $b^{*}$ values, which were measured in sextuplicate.

\subsection{Proximate composition}

The moisture, protein, lipid and ash contents were determined according to Latimer Junior (2012). The total carbohydrate levels and energy values were calculated using the formula proposed by Merrill and Watt (1973).

\subsection{Instrumental colour evaluation}

The instrumental colour parameters were determined for both the raw and cooked muscle portions, following the same procedure. CIE L* (lightness), $a^{*}$ (redness) and $b^{*}$ (yellowness) values were measured on both surfaces (one measurement on each side) of three cubic samples per muscle portion, using a Minolta CM-600D Spectrophotometer (Minolta Camera Co., Osaka, Japan) with illuminant A, $8 \mathrm{~mm}$ aperture and $10^{\circ}$ observer at $25^{\circ} \mathrm{C}$ (AMSA, 2012).

\subsection{Instrumental texture evaluation}

Hardness, chewiness, springiness and cohesiveness were measured using a TA.XT plus texture analyser (Stable Micro System, Surrey, UK) and analysed by the Texture Expert software package for Windows (R, Stable Micro System). Three cubic samples of each muscle portion were placed into the sample container and analysed with a P/36 probe. The test was carried out following the conditions proposed by Sun et al. (2015). 
Physicochemical and sensory characterization of three different portions from commercial pirarucu (Arapaima gigas) fillets Santos, J. S. L. et al.

\subsection{Sensory consumer testing}

One hundred and twenty-four participants (44 men and 80 women) ranging from 19 to 64 years old with a mean age of $41.5 \pm 31.8$ were randomly recruited. The sensory analyses were carried out in individual booths following a monadic sequential order and using a balanced block design. All participants provided a written informed consent before taking part, thus conforming with that established and approved by the Institutional Ethics Committee (45484315.0.0000.5243). The cooked samples $(2 \times 2 \times 2 \mathrm{~cm}$ each) from each muscle portion (cranial, medial and caudal) were served at $25^{\circ} \mathrm{C}$ on white plastic plates, coded with random 3 digit codes. Cream crackers without salt and filtered water at room temperature $\left(23^{\circ} \mathrm{C}\right.$ to $25^{\circ} \mathrm{C}$ ) were used to cleanse the palate between samples. The participants evaluated the appearance, colour, aroma, flavour, texture and overall liking using a nine-point hedonic scale (1- disliked extremely to 9- liked extremely) (DORNELLES et al., 2009; STONE; SIDEL, 1998). In addition, the participants also indicated their purchase intention with a five-point scale, ranging from $1=$ would certainly not buy to $5=$ would certainly buy.

\subsection{Statistical analyses}

The differences between the means obtained for the physicochemical and sensory parameters of the different muscle portions (cranial, medial and caudal) were detected by a one-way ANOVA with Tukey's post-hoc test. Pearson's correlation was applied to evaluate potential correlations between the proximate composition, sensory evaluation and instrumental colour and texture data of the cooked samples. In addition, a partial least squares regression (PLSR) was carried out to verify whether the determinant parameters contributed positively or negatively to the overall liking of the different muscle portions. All statistical analyses were carried out at a 95\% confidence level using the XLSTAT software (Addinsoft, Paris, France).

\section{Results and discussion}

\subsection{Proximate composition}

The cranial portion displayed higher $(P<0.05)$ moisture and carbohydrate levels, but lower $(P<0.05)$ lipid content and energy values than the other muscle portions (Table 1). Regarding the moisture, carbohydrate, lipid and energy values, no differences $(P>0.05)$ were observed between the medial and caudal portions. The cranial portion showed a higher $(P<0.05)$ ash content than the medial portion, followed by the caudal portion, with no differences $(P>0.05)$ observed between the protein levels of the different muscle portions. The great variability of the proximate composition of pirarucu fish flesh is well known, due to factors such as seasonal conditions, diet, age, sex and habitat (MARTINS et al., 2015). However, based on the results of the present study and on previous reports found in the literature, this variation is also detected in different body regions within the same fish (FOGAÇA et al., 2011; OLIVEIRA et al., 2014; SHAMIM et al., 2011).

In general, white muscle contains glycolytic fibres (white fibres), associated with fast movements, displaying low lipid contents and oxygen demands (LEE et al., 2010), whereas dark muscle comprises oxidative fibres (red fibres) related to constant slow swimming speeds, thus exhibiting high lipid contents and oxygen consumption rates (BERNAL et al., 2010; FAUSTMAN et al., 2010). Roy et al. (2012) reported that lipid accumulation in the muscle is related to the type of fibre, where slow-twitch oxidative (red) fibres contain higher lipid contents than fast-twitch glycolytic (white) fibres. This may explain the lower lipid content observed in the cranial muscle portion, suggesting that the $A$. gigas medial and caudal muscle portions are composed mainly of red fibres.

Scarce data on the proximate compositions of the cranial, medial and caudal portions of Arapaima gigas are available, but the results presented herein agree with previous studies found in the literature (FOGAÇA et al., 2011; OLIVEIRA et al., 2014). In addition, Guo et al. (2015) reported that the moisture and lipid levels are inversely related to each other, agreeing with the present findings.

Table 1. Proximate compositions and energy values of three different muscle portions of Arapaima gigas.

\begin{tabular}{ccrc} 
Parameters & \multicolumn{3}{c}{ Muscle portions } \\
\cline { 2 - 4 } Protein (\%) & \multicolumn{1}{c}{ Cranial } & \multicolumn{1}{c}{ Medial } & $16.60 \pm 0.18^{\mathrm{a}}$ \\
Lipid (\%) & $16.52 \pm 0.19^{\mathrm{a}}$ & $5.61 \pm 0.01^{\mathrm{a}}$ & $5.47 \pm 0.19^{\mathrm{a}}$ \\
Ash (\%) & $2.56 \pm 0.19^{\mathrm{b}}$ & $1.07 \pm 0.01^{\mathrm{b}}$ & $0.95 \pm 0.02^{\mathrm{c}}$ \\
Moisture (\%) & $1.11 \pm 0.03^{\mathrm{a}}$ & $76.19 \pm 0.33^{\mathrm{b}}$ & $76.52 \pm 0.20^{\mathrm{b}}$ \\
Carbohydrate (\%) & $78.26 \pm 0.20^{\mathrm{a}}$ & $0.42 \pm 0.12^{\mathrm{b}}$ & $0.46 \pm 0.06^{\mathrm{b}}$ \\
Energy value (kcal/100g) & $1.55 \pm 0.11^{\mathrm{a}}$ & $119.01 \pm 0.57^{\mathrm{a}}$ & $117.47 \pm 1.65^{\mathrm{a}}$ \\
\hline
\end{tabular}

Different letters in the same line indicate significant differences $(P<0.05)$. Results are expressed as the mean \pm standard deviation $(n=2)$. 


\subsection{Instrumental colour evaluation}

Raw cranial muscle showed lower $(P<0.05)$ $L^{*}$ and $a^{*}$ values as compared to the medial and caudal muscle portions, and the caudal portion exhibited the highest $(P<0.05) b^{*}$ values (Table 2$)$. These differences in the instrumental colour parameters may potentially be associated with the different fibre type composition of each muscle portion (BEKHIT; FAUSTMAN, 2005). Oxidative fibres, red and with a greater content of monounsaturated fatty acids (UTRERA et al., 2014) than glycolytic fibres, favour lipid oxidation, thereby increasing the $b^{*}$ values (MASNIYOM et al., 2013). Therefore, it is suggested that the medial and caudal muscle portions of $A$. gigas are mainly constituted of red fibres. To the best of our knowledge no studies involving the instrumental colour evaluation of the cranial, medial and caudal muscle portions of this fish species are available. However, red fibres obviously present a redder colour than white fibres, and the relationship between enhanced lipid oxidation and increased $b^{*}$ values in fish and fish products has been described previously (ERDMANN et al., 2017; HASSOUN; KAROUI, 2016; SÁEZ et al., 2015).

No differences $(P>0.05)$ were observed regarding the $L^{*}, a^{*}$ and $b^{*}$ values of the different cooked muscle portions, possibly due to colour changes after the cooking process (Table 2). Heat treatment causes protein aggregation and increases opacity, leading to decreasing optical path lengths in the fish flesh, and consequently the light introduced onto the surface presents a smaller chance of selective absorption (LARSEN et al., 2011). In the present study, all the cooked samples presented greater $L^{*}$ and $b^{*}$ values, but lower $a^{*}$ values as compared to the raw muscle portions. Similarly, Cofrades et al. (2011) reported that the cooking process decreased redness and increased lightness and yellowness in restructured poultry meat, resulting in a whiter coloration. Monteiro et al. (2015a) also observed that the cooking procedure increased the lightness and yellowness values, while decreasing the redness of restructured tilapia steaks, in agreement with the present findings.

\subsection{Instrumental texture evaluation}

Raw cranial muscle presented lower $(P<0.05)$ hardness and chewiness as compared to the other muscle portions, whereas raw medial muscle showed the greatest $(P<0.05)$ springiness (Table 2$)$. No difference $(P>0.05)$ was observed between the medial and caudal portions regarding hardness and chewiness, or in springiness between the cranial and caudal raw muscle portions. Cohesiveness was similar $(P>0.05)$ for the three different muscle portions. Muscle fibre size and number, as well as their composition and distribution, directly influence the meat texture parameters (LISTRAT et al., 2016). Ayala et al. (2005) reported that small fibres lead to a firmer texture in fish, while Hatae et al. (1990) observed a negative correlation between muscle fibre size and texture.

Table 2. Instrumental parameters of the three different muscle portions of Arapaima gigas.

\begin{tabular}{|c|c|c|c|}
\hline \multirow{2}{*}{ Parameters } & \multicolumn{3}{|c|}{ Muscle portions } \\
\hline & Cranial & Medial & Caudal \\
\hline \multicolumn{4}{|l|}{ Raw muscle } \\
\hline$L^{*}$ & $64.24 \pm 1.87^{b}$ & $68.42 \pm 3.75^{a}$ & $68.44 \pm 4.00^{\mathrm{a}}$ \\
\hline$a^{*}$ & $3.66 \pm 0.20^{b}$ & $5.56 \pm 0.52^{a}$ & $6.10 \pm 0.56^{a}$ \\
\hline$b^{*}$ & $8.62 \pm 0.66^{b}$ & $9.37 \pm 0.93^{b}$ & $11.85 \pm 1.13^{a}$ \\
\hline \multicolumn{4}{|l|}{ Cooked muscle } \\
\hline$L^{*}$ & $77.39 \pm 3.86^{a}$ & $76.80 \pm 3.37^{a}$ & $73.51 \pm 5.83^{\mathrm{a}}$ \\
\hline$a^{*}$ & $2.87 \pm 0.29^{a}$ & $2.70 \pm 0.36^{a}$ & $2.75 \pm 0.29^{a}$ \\
\hline$b^{*}$ & $12.66 \pm 1.25^{\mathrm{a}}$ & $13.09 \pm 1.30^{\mathrm{a}}$ & $13.07 \pm 1.32^{\mathrm{a}}$ \\
\hline \multicolumn{4}{|l|}{ Raw muscle } \\
\hline Hardness (N) & $24242.25 \pm 3027.52^{b}$ & $66040.60 \pm 7405.37^{a}$ & $62563.67 \pm 2859.02^{a}$ \\
\hline Chewiness $(\mathrm{g} \times \mathrm{mm})$ & $406.76 \pm 29.22^{b}$ & $1381.40 \pm 164.43^{a}$ & $1169.73 \pm 146.90^{a}$ \\
\hline Cohesiveness (g) & $0.48 \pm 0.04^{a}$ & $0.43 \pm 0.04^{a}$ & $0.47 \pm 0.04^{a}$ \\
\hline Springiness (mm) & $0.34 \pm 0.02^{b}$ & $0.48 \pm 0.03^{a}$ & $0.34 \pm 0.01^{b}$ \\
\hline \multicolumn{4}{|l|}{ Cooked muscle } \\
\hline Hardness (N) & $13855.63 \pm 776.32^{a}$ & $8788.75 \pm 536.97^{b}$ & $12841.94 \pm 850.09^{a}$ \\
\hline Chewiness $(\mathrm{g} \times \mathrm{mm})$ & $381.47 \pm 26.15^{b}$ & $209.40 \pm 19.14^{c}$ & $464.17 \pm 33.25^{a}$ \\
\hline Cohesiveness (g) & $0.44 \pm 0.02^{a}$ & $0.41 \pm 0.01^{a}$ & $0.47 \pm 0.05^{a}$ \\
\hline Springiness (mm) & $0.76 \pm 0.07^{\mathrm{a}}$ & $0.70 \pm 0.04^{a}$ & $0.80 \pm 0.07^{a}$ \\
\hline
\end{tabular}

Different letters in the same line indicate significant differences $(P<0.05)$. Results are expressed as the mean \pm standard deviation $(n=2)$. $L^{*}$ - lightness; $a^{*}$ - redness; $b^{*}$ - yellowness; $N$ - Newton; $g$ - grams. 
Physicochemical and sensory characterization of three different portions from commercial pirarucu (Arapaima gigas) fillets Santos, J. S. L. et al.

Oxidative fibres usually contain smaller fibres than glycolytic fibres (LISTRAT et al., 2016), justifying the results here presented. Again, no reports regarding the instrumental texture of the cranial, medial and caudal muscle portions of fish are available, although controversial differences in this parameter between other muscle regions have been described (CHAIJAN et al., 2010; RAWDKUEN et al., 2010). In partial agreement with the present results, Chaijan et al. (2010) observed that the dorsal portion of farmed giant catfish was harder than the ventral portion (Pangasianodon gigas). On the other hand, Rawdkuen et al. (2010) showed greater hardness for the ventral portion as compared to the dorsal muscle portion of this same species.

After the cooking procedure, the medial muscle demonstrated the lowest $(P<0.05)$ levels of hardness and chewiness (Table 2). The caudal portion exhibited the greatest $(P<0.05)$ chewiness, followed by the cranial muscle portion. No difference $(P>0.05)$ was observed in hardness between the cranial and caudal portions, or between the different cooked muscle portions with respect to cohesiveness and springiness. There is a lack of information regarding hardness, chewiness, cohesiveness and springiness of the different cooked muscle portions of this fish species. Nevertheless, the present results can potentially be attributed to the heat treatment applied (DUNAJSKI, 1980) in association with some muscle fibre characteristics such as size, amount, composition and distribution (LISTRAT et al., 2016). During cooking processes above $60{ }^{\circ} \mathrm{C}$, a condition applied in the present study, myofibrillar proteins are denatured, leading to textural changes mainly linked to meat tenderness (DUNAJSKI, 1980). When compared to mammalian collagen, fish collagen is less thermally stable and more soluble, due to the presence of proline and hydroxyproline, which play an important role in protein structure (HARRINGTON; VON HIPPEL, 1961). In addition, fish contain little connective tissue, and therefore fish textural properties depend predominantly on the myofibrillar protein arrangement (DUNAJSKI, 1980). After heating at $72{ }^{\circ} \mathrm{C}$, the cooked muscle portions demonstrated lower hardness and chewiness values than their raw counterparts. The same pattern was also observed by Aussanasuwannakul et al. (2012) and Monteiro et al. (2015b).

\subsection{Consumer testing evaluation}

All samples were highly acceptable regarding all the attributes evaluated in the acceptance test and for purchase intention, with scores above 7.0 and 4.0, respectively (Table 3$)$. No differences $(P>0.05)$ were observed regarding appearance, colour, aroma and texture attributes amongst the different muscle portions. Therefore the present results indicate that the sensory colour evaluation by consumers was in agreement with the instrumental colour data of the cooked muscle portions. On the other hand, the lower $(P<0.05)$ hardness and chewiness of the medial cooked muscle detected by the instrumental texture evaluation was not perceived by the consumers. Despite high correlations previously reported in the literature between the TPA and sensory evaluations (LARSEN et al., 2011; SHAVIKLO; FAHIM, 2014), no confirmatory studies on the relationship between instrumental and sensory analysis in texture measurements of different fish muscle portions are available. The medial and caudal muscle portions received higher $(P<0.05)$ scores for the flavour and overall liking attributes as compared to the cranial muscle portion. The high scores awarded for the flavour and overall liking of the medial and caudal muscle portions can be attributed to the correlation between lipid content and flavour ( $r=0.9750)$ and between flavour and overall liking $(r=0.9720)$ observed in the present study. This fact indicates that the higher $(P<0.05)$ lipid content of the medial and caudal muscle portions strongly contributed to the high flavour scores, and consequently the greater acceptability of these muscle portions than of the cranial muscle portion. This was also observed by Tobin et al. (2013), who noted lower acceptability scores for foods with reduced fat contents when compared to conventional fat content products, and by Vital et al. (2016), who observed good correlation between beef flavour $(r=0.882)$ and overall acceptability. Reinforcing these results, the PLSR

Table 3. Sensory attributes of the three different muscle portions of Arapaima gigas.

\begin{tabular}{cccc} 
Attributes & \multicolumn{3}{c}{ Muscle portions } \\
\cline { 2 - 4 } & Cranial & Medial & $7.17 \pm 1.27^{\mathrm{a}}$ \\
Appearance & $7.36 \pm 1.28^{\mathrm{a}}$ & $7.34 \pm 1.12^{\mathrm{a}}$ & $7.16 \pm 1.30^{\mathrm{a}}$ \\
Colour & $7.36 \pm 1.25^{\mathrm{a}}$ & $7.44 \pm 1.20^{\mathrm{a}}$ & $7.04 \pm 1.39^{\mathrm{a}}$ \\
Aroma & $7.36 \pm 1.35^{\mathrm{a}}$ & $7.36 \pm 1.30^{\mathrm{a}}$ & $8.14 \pm 0.78^{\mathrm{a}}$ \\
Flavour & $7.11 \pm 0.77^{\mathrm{b}}$ & $8.00 \pm 0.79^{\mathrm{a}}$ & $7.62 \pm 1.29^{\mathrm{a}}$ \\
Texture & $7.38 \pm 1.44^{\mathrm{a}}$ & $7.56 \pm 1.27^{\mathrm{a}}$ & $7.87 \pm 0.78^{\mathrm{a}}$ \\
Overall liking & $7.02 \pm 0.95^{\mathrm{b}}$ & $7.89 \pm 0.71^{\mathrm{a}}$ & $4.05 \pm 0.76^{\mathrm{a}}$ \\
\hline Purchase intention $^{*}$ & $4.08 \pm 0.80^{\mathrm{a}}$ & $4.10 \pm 0.75^{\mathrm{a}}$ & \\
\hline
\end{tabular}

Different letters in the same line indicate significant differences $(P<0.05)$; FPurchase intention was evaluated using a structured 5-point hedonic scale whereas the other attributes were evaluated using a 9-point hedonic scale. 


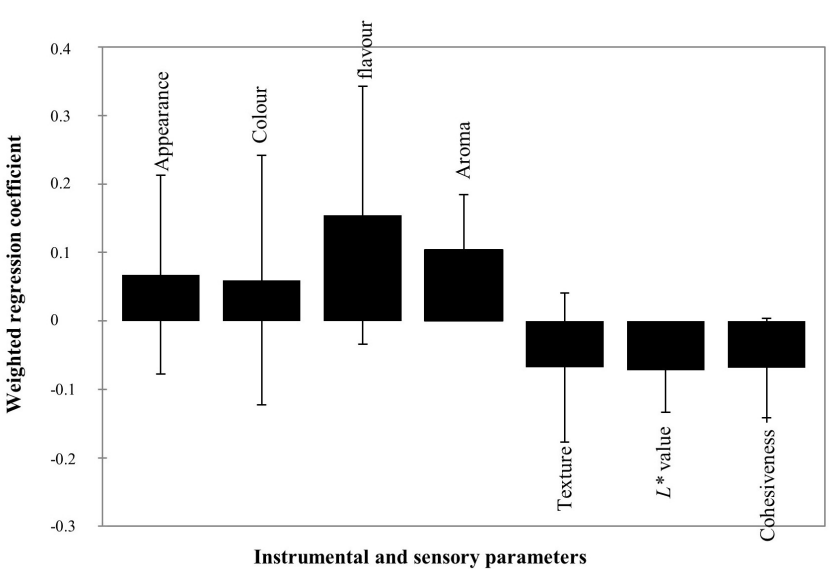

Figure 1. Weighted regression coefficients for the sensory attributes and instrumental parameters of consumer acceptance by partial least squares regression.

demonstrated that the sensory parameters of appearance, colour and aroma were determinants for acceptability, although flavour was the main attribute positively contributing to overall liking (Figure 1). The PLSR model explained $97.7 \%$ of consumer acceptance (Y-axis) and $95.9 \%$ of the sensory and instrumental parameters (X-axis), yielding an accumulated $Q^{2}$ of 0.973 . The nutritional, sensory and instrumental attributes were considered relevant when their respective variable importance in the projection was $>1.0$ (WOLD et al., 2001).

The sensory texture, $L$ *values and cohesiveness of the cooked muscle portions were detrimental for overall liking, however no difference $(P>0.05)$ was observed amongst the different muscle portions for these attributes. Although no difference $(P>0.05)$ was observed with regard to the purchase intention of the three different muscle portions, the medial and caudal muscle portions presented higher $(P<0.05)$ scores for flavour and overall liking. This fact may be explained by the influence of factors related to the purchase intention of foods. Despite the fact that overall liking is an important driving factor for purchase intention, the price and nutritional information also strongly contribute to consumer purchase intention (SOLHEIM; LAWLESS, 1996).

\section{Conclusions}

Although no correlation was observed between the instrumental and sensory parameters regarding texture, based on the findings of the present study, the medial and caudal muscle portions exhibited the highest lipid contents, which was determinant for high flavour and overall liking scores. Thus the authors suggest that the medial and caudal muscle portions are value added products for pirarucu, and may represent a strategic solution to encourage the commercialization of this important fish species.

\section{Acknowledgements}

The authors are grateful for the financial support provided by FAPERJ (grant numbers E-26/010.001954/2014, E-26/201.185/2014, $E-26 / 110.094 / 2014, E-26 / 010.001961 / 2014$, $E-26 / 010.001911 / 2014$, E-26/101.403/2014, E-26/202.305/2017, and E-26/202.306/2017); CNPq (grant numbers 311361/2013-7, 401922/2013-8, 313917/2013-2, 442102/2014-3, 441987/2014-1, and 150696/2017-5); and CAPES (grant number E-26/101.403/2014 - CAPES/ FAPERJ E-45 - PAPDRJ/2013).

\section{References}

AMERICAN MEAT SCIENCE ASSOCIATION - AMSA. Meat color measurement guidelines. 2nd ed. Champaign: AMSA, 2012. $125 \mathrm{p}$.

AUSSANASUWANNAKUL, A.; SLIDER, S. D.; SALEM, M.; YAO, J.; KENNEY, P. B. Comparison of variable-blade to Allo-Kramer shear method in assessing rainbow trout (Oncorhynchus mykiss) fillet firmness. Journal of Food Science, v. 77, n. 9, p. 335-341, 2012. http://dx.doi.org/10.1111/j.1750-3841.2012.02879.x. PMid:22897606.

AYALA, M. D.; LÓPEZ ALBORS, O.; BLANCO, A.; GARCÍA ALCÁZAR, A.; ABELLÁN, E.; RAMÍREZ ZARZOSA, G.; GIL, F. Structural and ultrastructural changes on muscle tissue of bass, Dicentrarchus labrax L., after cooking and freezing. Aquaculture, v. 250, n. 1-2, p. 215-231, 2005. http://dx.doi.org/10.1016/j. aquaculture.2005.04.057.

BEKHIT, A. E. D.; FAUSTMAN, C. Metmyoglobin reducing activity. Meat Science, v. 71, n. 3, p. 407-439, 2005. http://dx.doi. org/10.1016/j.meatsci.2005.04.032. PMid:22060917.

BERNAL, D.; DONLEY, J. M.; MCGILLIVRAY, D. G.; AALBERS, S. A.; SYME, D. A.; SEPULVEDA, C. Function of the medial red muscle during sustained swimming in common thresher sharks: contrast and convergence with thunniform swimmers. Comparative Biochemistry and Physiology Part A, v. 155, n. 4, p. 454-463, 2010. http://dx.doi.org/10.1016/j.cbpa.2010.01.005. PMid:20074658.

BREWER, M. S.; ZHU, L. G.; BIDNER, B.; MEISINGER, D. J.; MCKEITH, F. K. Measuring pork color: effects of bloom time, muscle, $\mathrm{pH}$ and relationship to instrumental parameters. Meat Science, v. 57, n. 2, p. 169-176, 2001. http://dx.doi.org/10.1016/ S0309-1740(00)00089-9. PMid:22061360.

CARDOSO, C. M. L.; MENDES, R.; NUNES, M. L. Instrumental texture and sensory characteristics of cod Frankfurter sausages. International Journal of Food Properties, v. 12, n. 3, p. 625-643, 2009. http://dx.doi.org/10.1080/10942910801992959.

CHAIJAN, M.; JONGJAREONRAK, A.; PHATCHARAT, S.; BENJAKUL, S.; RAWDKUEN, S. Chemical compositions and characteristics of farm raised giant catfish (Pangasianodon gigas) muscle. Food Science and Technology, v. 43, n. 3, p. 452-457, 2010. 
Physicochemical and sensory characterization of three different portions from commercial pirarucu (Arapaima gigas) fillets Santos, J. S. L. et al.

CHEN, T. Y.; CHIOU, T. K.; DING, N. F.; PAN, B. S. The impact of Carbon-Monoxide treatment on biochemical and sensorial quality of tilapia fillet during low temperature storage. Journal of Food and Nutrition Research, v. 3, n. 8, p. 502-512, 2015.

COFRADES, S.; LÓPEZ-LÓPEZ, I.; RUIZ-CAPILLAS, C.; TRIKI, M.; JIMÉNEZ-COLMENERO, F. Quality characteristics of low-salt restructured poultry with microbial transglutaminase and seaweed. Meat Science, v. 87, n. 4, p. 373-380, 2011. http://dx.doi. org/10.1016/j.meatsci.2010.11.014. PMid:21145666.

COPPES, Z.; PAVLISKO, A.; VECCHI, S. D. Texture measurements in fish and fish products. Journal of Aquatic Food Product Technology, v. 11, n. 1, p. 89-105, 2002. http://dx.doi.org/10.1300/ J030v11n01_08.

DORNELLES, A. S.; RODRIGUES, S.; GARRUTI, D. S. Aceitação e perfil sensorial das cachaças produzidas com Kefir e Saccharomyces cerevisae. Food Science and Technology, v. 29 , n. 3, p. 518-522, 2009. http://dx.doi.org/10.1590/S010120612009000300010.

DUNAJSKI, E. Texture in fish muscle. Journal of Texture Studies, v. 10, n. 4, p. 301-318, 1980. http://dx.doi.org/10.1111/j.1745-4603.1980. tb00862.x.

ERDMANN, M. E.; LAUTENSCHLAEGER, R.; ZEEB, B.; GIBIS, M.; WEISS, J. Effect of differently sized O/W emulsions loaded with rosemary extract on lipid oxidation in cooked emulsion-type sausages rich in n-3 fatty acids. Food Science and Technology, v. 79, p. 496-502, 2017.

FAUSTMAN, C.; SUN, Q.; MANCINI, R.; SUMAN, S. P. Myoglobin and lipid oxidation interactions: mechanistic bases and control. Meat Science, v. 86, n. 1, p. 86-94, 2010. http://dx.doi.org/10.1016/j. meatsci.2010.04.025. PMid:20554121.

FOGAÇA, F. H. S.; OLIVEIRA, E. G.; CARVALHO, S. E. Q.; SANTOS, J. F. S. Yield and composition of pirarucu fillet in different weight classes. Acta Scientiarum, Animal Sciences, v. 33, n. 1, p. 95-99, 2011. http://dx.doi.org/10.4025/actascianimsci.v33i1.10843.

FOOD AND AGRICULTURE ORGANIZATION - FAO. The state of world fisheries and aquaculture. Rome: FAO, 2016. 200 p.

FOOD AND DRUG ADMINISTRATION - FDA. Fish and fishery products hazards and controls guidance. 4th ed. Maryland: FDA, 2011. 468 p.

GUO, X.; LIANG, X. F.; FANG, L.; YUAN, X.; ZHOU, Y.; HE, S.; SHEN, D. Effects of lipid- lowering pharmaceutical clofibrate on lipid and lipoprotein metabolism of grass carp (Ctenopharyngodon idellal Val.) fed with the high non-protein energy diets. Fish Physiology and Biochemistry, v. 41, n. 2, p. 331-343, 2015. http://dx.doi.org/10.1007/s10695-014-9986-8. PMid:25213789.

HARRINGTON, W. F.; VON HIPPEL, P. H. The structure of collagen and gelatin. Advances in Protein Chemistry, v. 16, p. 1-138, 1961. PMid:13952907.
HASSOUN, A.; KAROUI, R. Monitoring changes in whiting (Merlangius merlangus) fillets stored under modified atmosphere packaging by front face fluorescence spectroscopy and instrumental techniques. Food Chemistry, v. 200, p. 343-353, 2016. http:// dx.doi.org/10.1016/j.foodchem.2016.01.028. PMid:26830598.

HATAE, K.; YOSHIMATSU, F.; MATSUMOTO, J. J. Role of muscle fibers in contributing firmness of cooked fish. Journal of Food Science, v. 55, n. 3, p. 693-696, 1990. http://dx.doi. org/10.1111/j.1365-2621.1990.tb05208.x.

KULAWIK, P.; MIGDAL, W.; TKACZEWSKA, J.; ÖZOGÜL, F. Assessment of color and sensory evaluation of frozen fillets from Pangasius catfish and Nile tilapia imported to European countries. International Journal of Food Properties, v. 19, n. 7, p. 1439-1446, 2016. http://dx.doi.org/10.1080/10942912.20 15. 1079790 .

LARSEN, D.; QUEK, S.; EYRES, L. Evaluating instrumental color and texture of thermally treated New Zealand king salmon (Oncorhynchus tshawytscha) and their relation to sensory properties. Food Science and Technology, v. 44, n. 8, p. 1814-1820, 2011.

LATIMER JUNIOR, G. W. (Ed.). Official methods of analysis of the Association of Official Analytical Chemists. 19th ed. Arlington: AOAC, 2012.

LEE, S. H.; JOO, S. T.; RYU, Y. C. Skeletal muscle fiber type and myofibrillar proteins in relation to meat quality. Meat Science, v. 86, n. 1, p. 166-170, 2010. http://dx.doi.org/10.1016/j. meatsci.2010.04.040. PMid:20605337

LISTRAT, A.; LEBRET, B.; LOUVEAU, I.; ASTRUC, T.; BONNET, M.; LEFAUCHEUR, L.; PICARD, B.; BUGEON, J. How muscle structure and composition influence meat and flesh quality. The Scientific World Journal, v. 2016, p. 1-14, 2016. http://dx.doi. org/10.1155/2016/3182746. PMid:27022618.

LIU, Y.; LYON, B. G.; WINDHAM, W. R.; REALINI, C. E.; PRINGLE, T. D.; DUCKETT, S. Prediction of color, texture, and sensory characteristics of beef steaks by visible and near infrared reflectance spectroscopy: a feasibility study. Meat Science, v. 65, n. 3, p. 1107-1115, 2003. http://dx.doi.org/10.1016/S03091740(02)00328-5. PMid:22063693.

MANCINI, R. A.; HUNT, M. C. Current research in meat color. Meat Science, v. 71, n. 1, p. 100-121, 2005. http://dx.doi.org/10.1016/j. meatsci.2005.03.003. PMid:22064056.

MARTINS, M. G.; MARTINS, D. E. G.; SILVA, P. R. Drying kinetics and hygroscopic behavior of pirarucu (Arapaima gigas) fillet with different salt contents. Food Science and Technology, v. 62, n. 1, p. 144-151, 2015.

MASNIYOM, P.; BENJAMA, O.; MANEERI, J. Effect of modified atmosphere and vacuum packaging on quality changes of refrigerated tilapia (Oreochromis niloticus) fillets. International Food Research Journal, v. 20, n. 3, p. 1401-1408, 2013. 
Physicochemical and sensory characterization of three different portions from commercial pirarucu (Arapaima gigas) fillets Santos, J. S. L. et al.

MERRILL, A. L.; WATT, B. K. Energy value of foods: basis and derivation. Washington: ARS United States Department of Agriculture, 1973. $105 \mathrm{p}$

MOLINA, B.; SÁEZ, M. I.; MARTÍNEZ, T. F.; GUIL-GUERRERO, J. L.; SUÁREZ, M. D. Effect of ultraviolet light treatment on microbial contamination, some textural and organoleptic parameters of cultured seabass fillets (Dicentrarchus labrax). Innovative Food Science \& Emerging Technologies, v. 26, p. 205-213, 2014. http://dx.doi.org/10.1016/j.ifset.2014.07.002.

MONTEIRO, M. L.; MÁRSICO, E. T.; LÁZARO, C. A.; CANTO, A. C. S.; LIMA, B. R.; CRUZ, A. G.; CONTE-JÚNIOR, C. A. Effect of transglutaminase on quality characteristics of a value-added product tilapia wastes. Journal of Food Science and Technology, v. 52, n. 5, p. 2598-2609, 2015a. http://dx.doi.org/10.1007/ s13197-014-1327-5. PMid:25892758.

MONTEIRO, M. L. G.; MÁRSICO, E. T.; CANTO, A. C. V. C. S.; COSTA LIMA, B. R. C.; LÁZARO, C. A.; CRUZ, A. G.; CONTEJÚNIOR, C. A. Partial sodium replacement in tilapia steak without loss of acceptability. Food Science \& Technology International, v. 21, n. 4, p. 295-305, 2015b. http://dx.doi. org/10.1177/1082013214535229. PMid:24831644.

OLIVEIRA, P. R.; JESUS, R. S.; BATISTA, G. M.; LESSI, E. Sensorial, physicochemical and microbiological assessment of pirarucu (Arapaima gigas, Schinz 1822) during ice storage. Brazilian Journal of Food Technology, v. 17, n. 1, p. 67-74, 2014. http:// dx.doi.org/10.1590/bjft.2014.010.

RAWDKUEN, S.; JONGJAREONRAK, A.; PHATCHARAT, S.; BENJAKUL, S. Assessment of protein changes in farmed giant catfish (Pangasianodon gigas) muscles during refrigerated storage. International Journal of Food Science \& Technology, v. 45 , n. 5, p. 985-994, 2010. http://dx.doi.org/10.1111/j.13652621.2010.02217.x

RINCÓN, L.; CASTRO, P. L.; ÁLVAREZ, B.; HERNÁNDEZ, M. D.; ÁlVAREZ, A.; CLARET, A.; GUERRERO, L.; GINÉS, R. Differences in proximal and fatty acid profiles, sensory characteristics, texture, colour and muscle cellularity between wild and farmed blackspot seabream (Pagellus bogaraveo). Aquaculture, v. 451, p. 195-204, 2016. http://dx.doi.org/10.1016/j.aquaculture.2015.09.016.

ROY, B. C.; ANDO, M.; NAKATANI, M.; OKADA, T.; SAWADA, Y.; ITOH, T.; TSUKAMASA, Y. Muscle fiber types, growth and development in the whole myotome of cultured Pacific bluefin tuna Thunnus orientalis. Fisheries Science, v. 78, n. 2, p. 471-483, 2012. http://dx.doi.org/10.1007/s12562-011-0463-3.

SÁEZ, M. I.; MARTÍNEZ, T. F.; CÁRDENAS, S.; SUÁREZ, M. D. Effects of different preservation strategies on microbiological counts, lipid oxidation and color of cultured meagre (Argyrosomus regius, L.) fillets. Journal of Food Processing and Preservation, v. 39, n. 6, p. 768-775, 2015. http://dx.doi.org/10.1111/jppp. 12286.

SHAMIM, A. H.; AHMED, K.; ABDULLAH, A. T. M. Proximate composition of different portion of Hilsa, Tenualosa ilisha from two regions of the bay of Bengal in Bangladesh. Dhaka University
Journal of Biological Sciences, v. 20, n. 2, p. 109-115, 2011. http://dx.doi.org/10.3329/dujbs.v20i2.8970.

SHAVIKLO, A. R.; FAHIM, A. Quality improvement of silver carp fingers by optimizing the level of major elements influencing texture. International Food Research Journal, v. 21, n. 1, p. 283-290, 2014.

SOLHEIM, R.; LAWLESS, H. T. Consumer purchase probability affected by attitude towards low-fat foods, liking, private body consciousness and information on fat and price. Food Quality and Preference, v. 7, n. 2, p. 137-143, 1996. http://dx.doi. org/10.1016/0950-3293(95)00045-3.

STONE, H.; SIDEL, J. L. Quantitative descriptive analysis: developments, applications, and the future. Food Technology, v. 5, p. $48-52,1998$.

SUN, T.; HAO, W.; LI, J.; DONG, Z.; WU, C. Preservation properties of in situ modified CaCO3-chitosan composite coatings. Food Chemistry, v. 183, p. 217-226, 2015. http://dx.doi.org/10.1016/j. foodchem.2015.03.036. PMid:25863631.

TOBIN, B. D.; O'SULLIVAN, M. G.; HAMILL, R.; KERRY, J. P. The impact of salt and fat level variation on the physiochemical properties and sensory quality of pork breakfast sausages. Meat Science, v. 93, n. 2, p. 145-152, 2013. http://dx.doi.org/10.1016/j. meatsci.2012.08.008. PMid:23022579.

UTRERA, M.; PARRA, V.; ESTEVEZ, M. Protein oxidation during frozen storage and subsequent processing of different beef muscles. Meat Science, v. 96, n. 2, p. 812-820, 2014. http:// dx.doi.org/10.1016/j.meatsci.2013.09.006. PMid:24200575.

VÁCHA, F.; STEJSKAL, V.; VEJSADA, P.; KOURIL, J.; HLAVÁC, $D$. Texture profile analyses in tench (Tinca tinca L., 1758) from extensive and intensive culture. Acta Veterinaria Brno, v. 82, n. 4, p. 421-425, 2013. http://dx.doi.org/10.2754/avb201382040421.

VITAL, A. C.; GUERRERO, A.; MONTESCHIO, J. O.; VALERO, M. V.; CARVALHO, C. B.; ABREU FILHO, B. A.; MADRONA, G. S.; PRADO, I. N. Effect of edible and active coating (with rosemary and oregano essential oils) on beef characteristics and consumer acceptability. PLoS One, v. 11, n. 8, p. 1-15, 2016. http://dx. doi. org/10.1371/journal.pone.0160535. PMid:27504957.

WOLD, S.; SJOSTROM, M.; ERIKSSON, L. PLS-regression: a basic tool of chemometrics. Chemometrics and Intelligent Laboratory Systems, v. 58, n. 2, p. 109-130, 2001. http://dx. doi. org/10.1016/S0169-7439(01)00155-1.

XIONG, R.; CAVITT, L. C.; MEULLENET, J. F.; OWENS, C. M. Comparison of Allo-Kramer, Warner-Bratzler and razorblade shears for predicting sensory tenderness of broiler breast meat. Journal of Texture Studies, v. 37, n. 2, p. 179-199, 2006. http:// dx.doi.org/10.1111/j.1745-4603.2006.00045.x. 